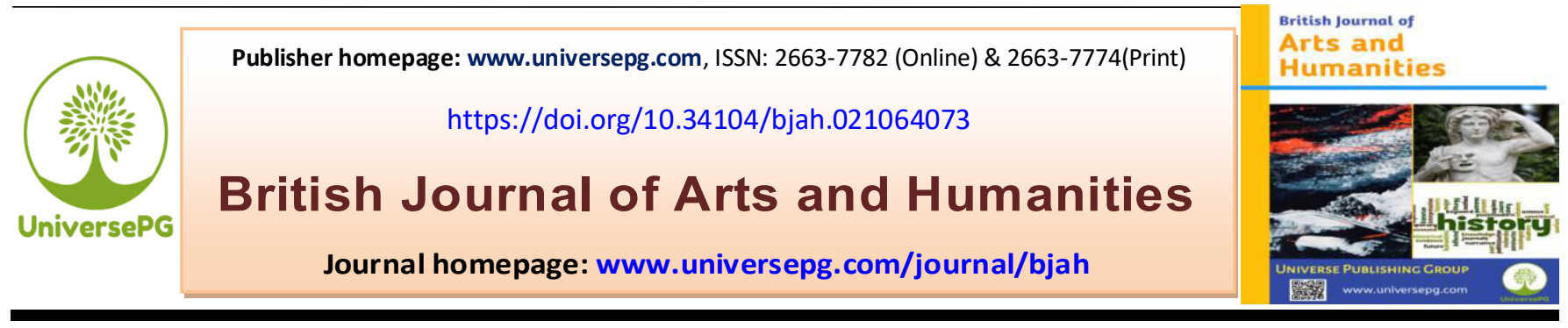

\title{
Impact of Primary Schools Infrastructure on the Dropout Rate: A Situational Analysis on the Context of Bangladesh
}

\author{
Mahmudul Hasan ${ }^{1}$, Md. Mokter Ali ${ }^{1 *}$, Mst. Tahmina Sultana ${ }^{1}$, and Rehena Parvin ${ }^{1}$ \\ ${ }^{1}$ Department of Sociology and Social Work, Gono Bishwabidyalay (University), Mirzanagar, Savar, Dhaka, Bangladesh. \\ *Correspondence: dipugb@gmail.com (Md. Mokter Ali, Senior Lecturer, Department of Sociology and Social Work, \\ Gono Bishwabidyalay (University), Mirzanagar, Savar, Dhaka-1344, Bangladesh).
}

\begin{abstract}
The objectives of this research were to discover the impact of primary school infrastructure and resources on the dropout rate of primary schools in Bangladesh. This study also includes the other circumstances of student dropout from the primary schools of Bangladesh. The main method of this study was an interview survey and also used Focus Group Discussions (FGD). The primary data have been collected from study areas which are four districts of Bangladesh (Dhaka, Gazipur, Shariatpur, and Tangail) and secondary ones from different relevant publications, books, dissertations, journal articles, government publications, and websites. The current literacy rate has increased in Bangladesh. But the stall factor remains the main obstacle to reaching this objective. So far, an enumerated number of students do not pursue their studies for many reasons. The vulnerable condition of the infrastructure and the scarcity of resources in these schools are the principal causes. Some of the survey data are presented here, like $8.1 \%$ primary schools are tin-shed +mosaic floor construct, $14 \%$ school's doors and windows are broken, and $21.6 \%$ school is unsanitary. Ultimately, this study found that, on average, $6.68 \%$ of students were dropped out of primary school because of a broken infrastructure. It's a massive obstacle to acquiring a 100\% literacy rate. Moreover, Simple Linear Regression Analysis found more authentic speculation as to the cause of the dropout of the students from the primary level. This survey found that 'Infrastructural facilities' and 'Apparent of Buildings' are more efficiently related. With a P-value of $0.005 \mathrm{~b}$, this is less than the significant level of 0.05 . The linear regression model was found to be an excellent fit. In this research, we focused on a specific cause of dropout and wanted to pinpoint the margin of the problem. Hopefully, this research will make a meaningful contribution to the field of knowledge.
\end{abstract}

Keywords: Infrastructure, Dropout, Primary school, Analysis, Education, Impact, and Context of Bangladesh.

\section{INTRODUCTION:}

There are a lot of causes of student dropout in Bangladesh. One of the major causes of student dropout in Bangladesh is the broken Infrastructure of primary school. Bangladesh government is trying to build good construction for protecting student dropout. But still, it's a monumental task to finish and its main barrier is the financial crises. Nonetheless, how to propose an UniversePG I www.universepg.com accurate logic and target from many other difficulties. Different social, economic and political issues are related to student dropout (Zaman, 2014). School infrastructure, basically building is directly related to academic achievement (Durán-Narucki, 2008). This research was conduct for how to get an appropriate investigation of which procedures to socially significant and important for scientific analysis, and how to 
trace a research question that is relevant to scientific theory. In these circumstances, the objective of this research is to find out the impact of school infrastructure on the rate of dropout. A lot of research has been conducted on dropout. They have shown a lot of causes. But there is little research conducted on a special cause that uniquely impacts dropout. This research finds that $6.68 \%$ (Table 1) students are directly drops out of the infrastructural crisis. So, our study indicates that broken infrastructure is direct related to student dropout. Moreover, this study will help to find out the dominance of a single cause that is re-constructible and will help the responsible authority to find a solution.

\section{Literature Review}

Those who have left the school, college and universities that are call dropout. Dropouts are someone who has left school or college before they have not completed their study in particular educational institutions (Cambridge Dictionary). The rate of dropout from primary schools in the Third World has declined slightly over the past few decades but has not reached the expected level. According to the Annual Primary School Census 2017 of Bangladesh, the dropout rate in primary education is $18.8 \%$. That is why it has turned into a popular research field for researchers. A lot of research been conducted on this context in Bangladesh but very little work has been done on the tendency of students to dropout due to infrastructure.

Infrastructure indicates that school building, basic student's facilities (like, hygiene's toilet, watch room, reading room, seminar-library, computer, water supplies, etc.), classroom's furniture, construction environment, floor-class room-black board design, siting capacity in a class room, and electricity. So, dropout is also depending on various things. But the major cause is the facilities what schools are producing. Insufficient sanitation facilities in schools extremely affect girls' dropout because this insufficiency indicates that schools are not safe for girls (Lizettee, 2000). This study highlights on dropout students those who are not finishing his or her study from class one to class five that is call primary level. The rate of dropout of primary education students is till now a threat to achieving a $100 \%$ literacy rate. Children are admitting in primary schools rapidly than the previous time but in many low-income countries, the rate of children dropout from schools remains high where almost half of the total students who start primary school do not accomplish their education (Sabates et al., 2010). There is very few research conducted on student dropout due to the school infrastructure in Bangladesh. Sabates et al. (2010) looked at the connection between student dropout and longitudinal evidence. Nazirul et al. (2019) mentioned in another study. In another study, (Durán-Narucki, 2008) examined School building condition with the school attendance, and academic achievement. Some classic reviews (Edmonds, 1979; Levine \& Lezotte, 1990; Purkey \& Smith, 1990) and also some modern reviews (Cotton, 1995; Sammons et al., 1995; Scheerens \& Bosker, 1997) say students' achievements depend on school resources and school facilities. In Latin America, school resources and facilities are associated with student's performance (Murillo, 2007b; Ve' lez et al., 1994). School-level factors play a vital role in increasing pressures to dropout such as teacher absenteeism, school location and poor-quality educational provision (Islam, 2020; Alexander, 2008).

Muhammad Shahid Farooq shows a model to Prevent Dropout from Primary Schools in Pakistan by showing that there are 158,378 primary schools situated in Pakistan which contains 17,043,460 students and also 447,890 teachers them. Where $37.8 \%$ of schools without fences, $32.3 \%$ without drinking water, $56.4 \%$ without electricity, $40.5 \%$ without toilets and $6.8 \%$ without building (Ministry of Finance, 2008).

So, this infrastructural crisis hampers' Pakistan's education system also. Equally, Bangladesh facing the same problems in the primary level of education. So, the mixed method (Qualitative plus Quantitative) of research helped to analyze the rate of dropout from primary school level. We hope that the collected data for the study should also provide an effective and analyze of the student dropout from the primary education level of Bangladesh and fulfil the knowledge gap that we found from the review of literature.

\section{Study Objectives}

- The main objective of the research was to investigate the student dropout in the primary education level at Bangladesh based on the infrastructural crisis and resources of the school. 
- The specific objectives of this study were to collect the opinion of primary section school teachers about student dropout.

- Observe and document the present infrastructural condition of the primary schools of Bangladesh.

\section{METHODOLOGY:}

Research Approach and Data Collection - The researchers used a mixed-method (Qualitative plus Quantitative) research approach to collect data and conduct four focus group discussions (FGD) in four districts and used a survey method to collect the data. The study data were collected from first February to June 2020. So, the data was collected just before and during the time of the Corona pandemic situation. That is why; we were unable to interview the dropped students and also a big challenge for collecting virgin data or information from the field level. On the other hand, it was very important to interview the dropout students to verify the collecting data and information that was used in this study. But since that was not possible, so, the researcher used a mixed-methods approach in the study. So, it's helped to facilitate triangulation. Moreover, this study seeks to show a comparative similarity of the primary data with other research data, that is why this research will be more impartial usefulness.

Study area and location - This research is focused on the primary student dropout and based on four districts of Bangladesh. We included schools from both urban and village levels. So, we have selected primary schools from two mostly urbanized districts (Dhaka, Gazipur) and two rural area-based districts (Tangail, Shariatpur). The schools are from Dhaka (10 Schools), Gazipur (9 schools), Tangail (9) and Shariatpur (9), a total of 37 schools. We have taken two Upazilas of every district under our consideration. From Dhaka we have chosen Savar and Dhamrai Upazila; from Gazipur-Gazipur Sadar and Sripur Upazila; from Shariatpur-Shariatpur Sadar and Naria Upazila; from TangailSakhipur and Kalihati Upazila.
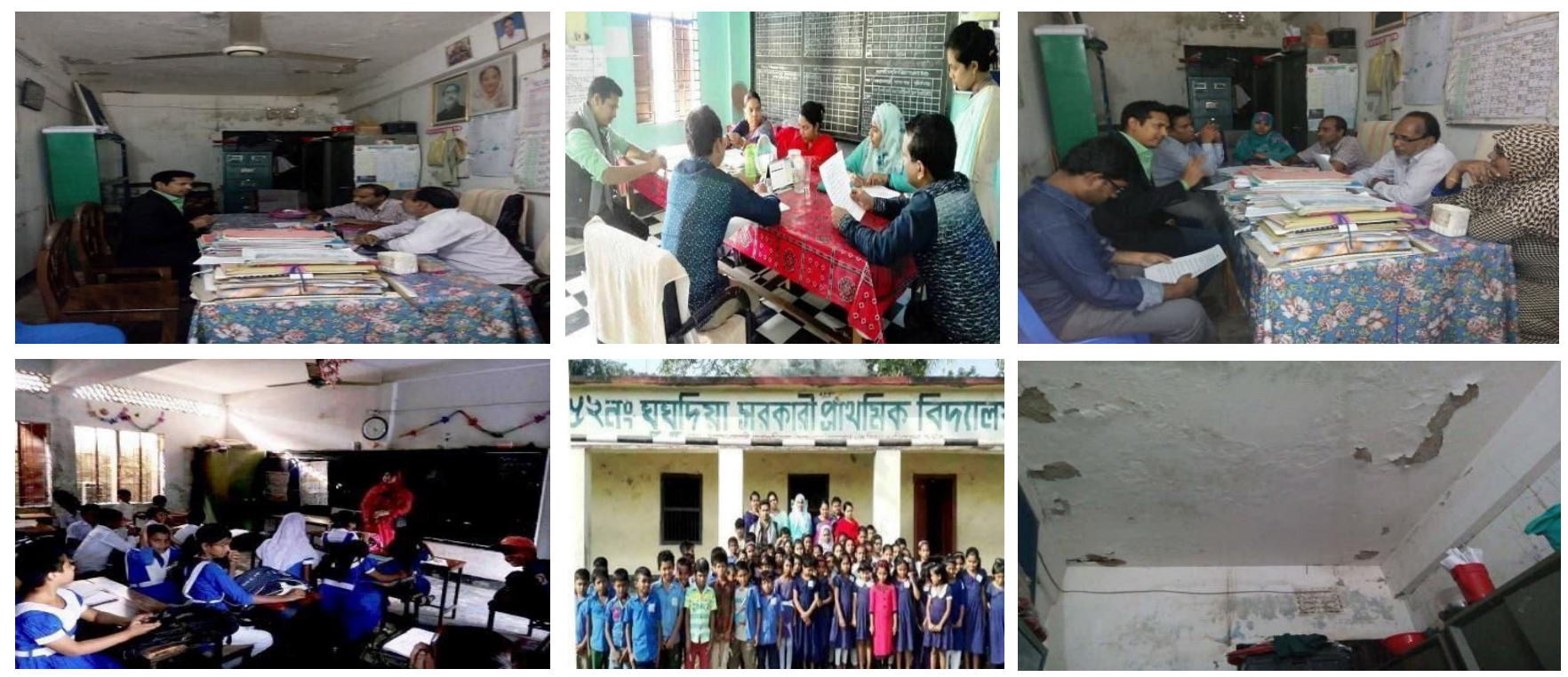

Some image of study area (2020).

Sample Size and Sampling Procedures - This study took 37 schools as a sample from four districts of Bangladesh. These schools are from both village and urban areas. So, we think that collected data from these 37 schools are capable to represent all of the primary schools of Bangladesh. This research used a Multi purposive sampling method to select primary schools. First researchers selected four districts (Dhaka, Gazipur, Tangail, \& Shariatpur), then selected 8 Thana UniversePG I www.universepg.com
(Upazila), after that randomly selected 16 union Parishad, then 37 school finds from 16 union Parishad.

Selection of School and Respondents - The researchers selected all those schools that were founded at least 10 years ago. This has made it easier to know the history of dropout. All those schools have a long tradition, a reputation at the local level; also govt. affiliated and provided all govt. facilities to the student's academic achievement besides controlling student 
dropout. We interviewed all the head Masters of 37 primary schools and in-depth interview as a KII (Key Informant Interview) person of respondents. In this Covid-19 pandemic situation, the study would not be possible if the headmasters didn't provide data (also some teachers, in the FGD context). But there were no further opportunities to verify whether the students who are dropout due to the school's infrastructure. If this data and information would be collected by going door to door to the students who were dropped out, then the study would be more rational.

Data Analysis Techniques: Triangulation - Data from school survey, in-depth interview, FGDs, KIIs, check out of school's attendant's kata (register book), documentary analysis. The research question and design framework and this study used SPSS, Microsoft Excel and statistical methods to analyze the data and also used Simple Linear Regression Model:

$\mathrm{Y}=\boldsymbol{\beta 0}+\beta 1 \mathrm{X} 1+\beta 2 \mathrm{X} 2+\beta 3 \mathrm{X3}+\mathrm{e}$

Where,

$\mathrm{Y}=$ Apparent of Building

Table 1: Total Dropout (School and class wise) $\beta \mathrm{o}=$ Constant

B1-B3 = Beta coefficients

$\mathrm{X} 1=$ Total numbers of class room

$\mathrm{X} 2$ = Apparent of doors, windows and roofs

$\mathrm{X} 3=$ Total numbers of toilet

$\mathrm{e}=$ Error Term

\section{RESULTS:}

\section{A. Descriptive Analysis}

Total Dropout: School wise - Table 1 shows schools and class wise dropouts. Collected information from the all 37 primary schools of the study area shows that total consists of 2080 students and the average in this class is 56.22. Total dropout of the students from class one is 25 and the percentage is 1.2. Like that, from class two the rate of dropout is $1.48 \%$, from class three $1.65 \%$, from class four $1.27 \%$ and from class five $1.05 \%$. This study finds that, the maximum number of dropouts happens in class three, which is $1.65 \%$ and the total number of dropouts by this study is $6.68 \%$.

\begin{tabular}{|l|c|c|c|c|c|}
\hline \multicolumn{7}{|c|}{ Total Dropout (School and class wise) } \\
\hline & N / Total School & Sum & Mean & Total Dropout & \% Of Dropout \\
\hline Total Students in Class One & 37 & 2080 & 56.22 & 25 & $1.20 \%$ \\
\hline Total Students in Class Two & 37 & 2163 & 58.46 & 32 & $1.48 \%$ \\
\hline Total Students in Class Three & 37 & 2303 & 62.24 & 38 & $1.65 \%$ \\
\hline Total Students in Class Four & 37 & 2198 & 59.41 & 28 & $1.27 \%$ \\
\hline Total Students in Class Five & 37 & 2035 & 55.00 & 22 & $1.08 \%$ \\
\hline Valid N (leastwise) & 37 & 10779 & 58.27 & 145 & $6.68 \%$ \\
\hline
\end{tabular}

School Apparent: Buildings, Doors, Windows and

Roofs - Maximum number of the primary school infrastructures of Bangladesh are constructed by bricks, one stored, multi-stored buildings and tin shed-mosaic floor structures. We observed the maximum number of schools have brick made buildings. The Bangladesh government has taken good initiatives to establish brick made buildings for the primary schools of this country. In the riverbank areas like naria, shariatpur this primary school building being used as a multiflood and cyclone center for the local people. So, government primary schools are mostly brick made buildings. In Fig 1 (Types of building construction) $62.2 \%$ schools are one-stored buildings and multi-stored brick buildings are $29.7 \%$. Besides $8.1 \%$ schools are made by Mosaic floor + Tin-shade walls. At some cases, we have identified that some schools have two or more buildings. One of them is made up of bricks and another is concrete floor or tin shed-mosaic floor building. Majority number of doors and windows are made of steel and some are wooden. This study found mostly $70 \%$ of doors, windows and roofs are in good shape (Fig 1; Doors, Windows and Roofs). But some schools haven't good doors and windows and this is $14 \%$ by our collected data. 


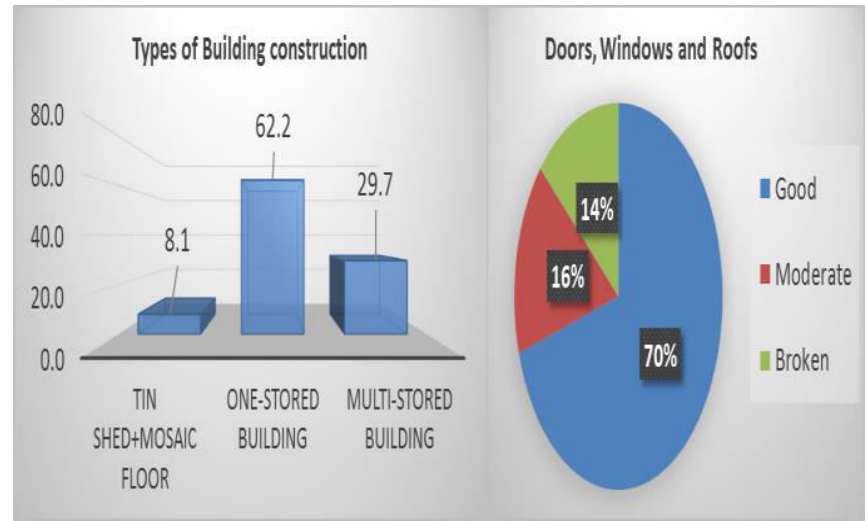

Fig 1: Types of building construction, doors, windows $\&$ roofs.

Some of these doors and windows are broken and some are rotten by rainwater. A few school buildings we found which have holes in the roof. In the rainy season, rainwater comes through these holes into the classroom and damages the wooden benches. Students suffer from this problem several times. Beside this we observe in Fig 1, 16\% of schools have moderate doors, windows and roofs. So, school building condition is the major indicators for students drooping. Duran and Narucki raise same argument for dropping out from primary level (Durán-Narucki, 2008). Qualitative investigation (FGD): we found some rooms have become unusable for its broken doors and windows. As these schools are struggling for the scarcity of rooms. So, this damaged room costs the school very much. Some schools' teachers told that 'we have to take jampack classes for the room scarcity and some-times they take even two classes at a time'.

Total rooms, classrooms and useless rooms - Fig 2 (Total rooms, class rooms and useless rooms) shows the entire number of rooms in a particular school. It includes both classrooms and teachers' rooms. In Fig 2, digram-1 in mentioned here series 1 shows the number of schools, series 2 shows percentage and $\mathrm{X}$ axis (1-20) show number of rooms. Here, among 37 primary schools, 2 schools have 4 rooms which are $5.4 \%$ of total schools. Besides this 7, 11, 14 and 18 rooms consist of 2 schools. But mostly 20 rooms consist only one school. 7 schools have 6 rooms which are $18.9 \%$ and this is the highest percentage. That means the highest number of schools has 6 rooms. Relatively 6 schools have 12 classrooms which are 16.2\%. 5 schools have 8 rooms and another 5 schools have 5 rooms. Contrariwise, comparatively very few numbers of schools have enough classrooms. Fig 2 (digram-2, Class Rooms) shows classrooms in $\mathrm{X}$-axis (1-15) and school percentage is in Y-axis. Here, $8.1 \%$ of school has 15 classrooms. $2.7 \%$ of school has 11 classrooms, $13.5 \%$ of school has 10 classrooms, and $8.1 \%$ of schools have 8 and 9 classrooms. These numbers of classrooms are enough for those schools. But, in comparison, $27 \%$ of schools have only 5 classrooms, $16.2 \%$ of schools have 4 classrooms and $5.4 \%$ of schools have just 3 classrooms.

Besides the scarcity of rooms some school contains some useless rooms. Fig 2 (Useless rooms) shows that $16 \%$ of school has 1-2 useless rooms, $14 \%$ of schools have 3-4 useless rooms and 5\% of schools have more than five useless rooms. Though $65 \%$ of schools have no useless rooms, even so, it's a great problem for teachers to manage a large number of students in these small numbers of classrooms.
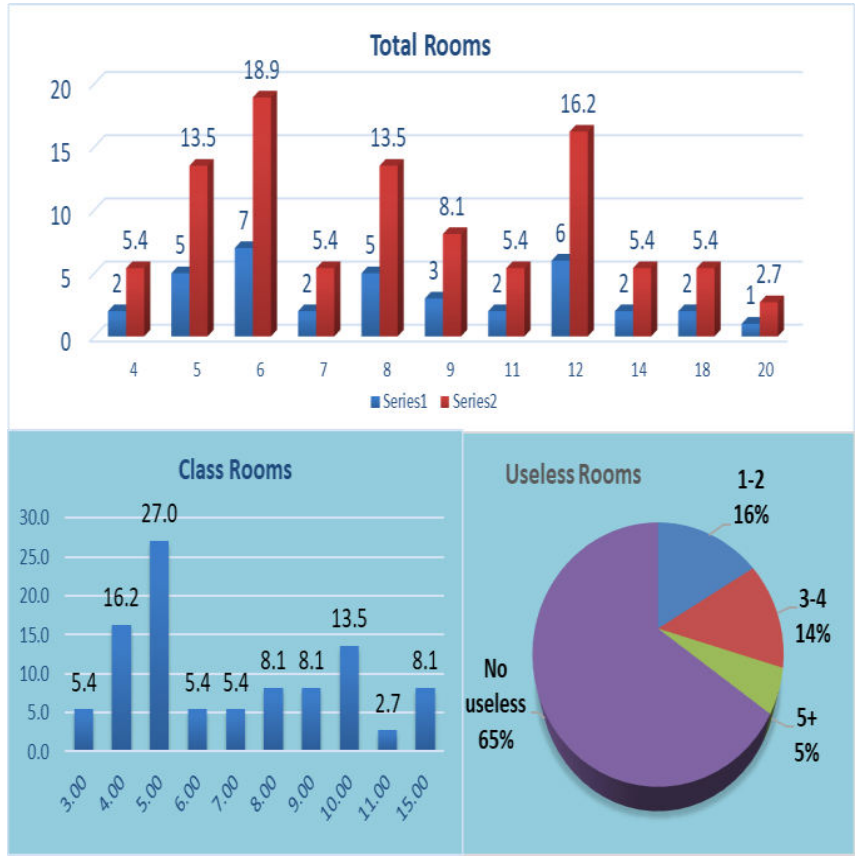

Fig 2: Total rooms, class rooms, \& useless rooms.

Qualitative investigation (FGD): From the discussion we get experienced that greater portion of the school is mediocre size. Excluding teachers' room and headmasters' room they left a limited number of class rooms to take classes properly. Teachers informed that sometimes they need to create two or more sections to manage a big number of students within a few numbers of rooms and Fig $\mathbf{2}$ proves that statement. 
Sanitation Condition - This research found, lack of Toilets and Urinals for the students. In many cases, school-going children don't know the importance and how its use. Especially in remote areas, this number is very much terrible. Fig 3 (Total Number of Toilets) shows that 20 schools have just two toilets which are around $54 \%$. How only two toilets can be sufficient for all the students and staffs for a school? When we searched for the information about urinals, we fond also some naked truth. $62.2 \%$ of school have no separate urinals (Fig 3; Total number of urinals). $18.9 \%$ have 1 urinal and $18.9 \%$ have 2 . So, maximum school has no urinals and those who have, all are not sanitary yet. In Fig 3 (Apparent of urinals), 2.7\% urinals are very unsanitary and $16.2 \%$ are unsanitary.
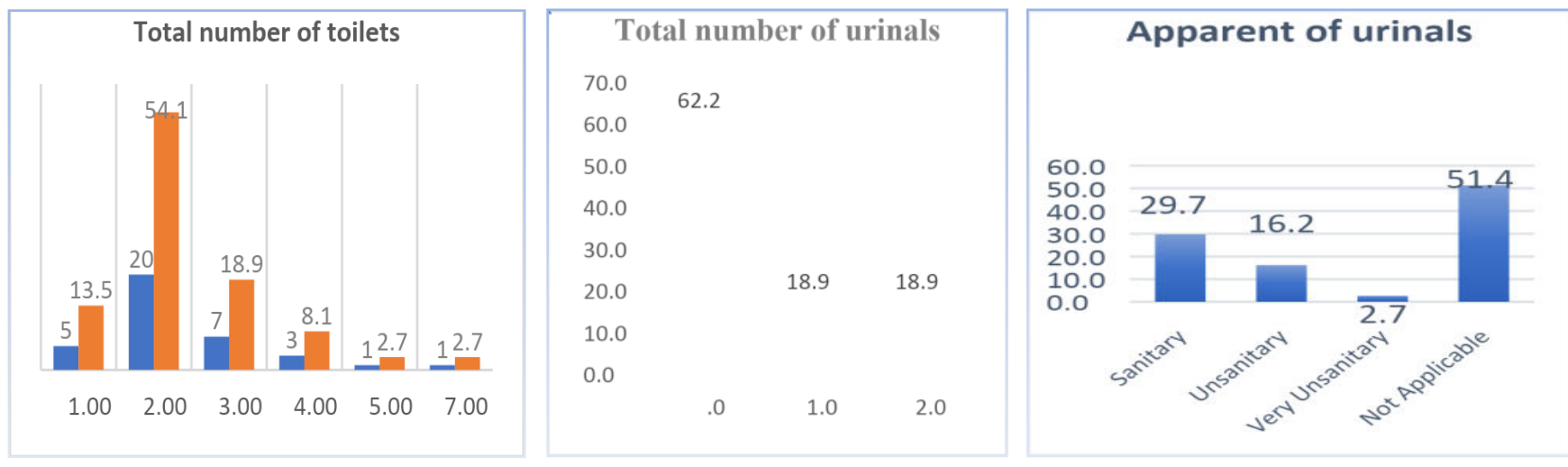

Fig 3: Number of toilets, urinals and apparent of urinals.

Qualitative investigation (FGD): We talked with teachers and a very few students on this topic. All of them said the toilets and urinals they have is not sufficient yet. They don't have urinals in many cases. So, children use school compounds some times. It's very unhealthy for them. Students said the status of the toilet is very unhygienic. It's not cleaned properly. Government of Bangladesh is trying very hard to generate awareness within the school going children to use soap after using toilet. Because not using soap after using the toilet is the source of utmost diseases. But this research found maximum schools they don't use soap after using the toilet. Even maximum school doesn't serve soap for students. Though the percent of soap use is increasing which is more than fifty percent but still the non-use rate is very much high. Students of rural area schools said they don't know the necessity of using soap after toilet. Few of them use mud after using the toilet. In the urban areas' families are aware of this but the condition of the toilets in schools is very unhygienic, they complained.

Condition of Play Grounds - Sport is the biggest effective agent of mental development. So, we wanted to investigate the scenario of the playgrounds of the survey area. At Fig 4 we can see that $37.8 \%$ of schools have big playgrounds. But the terrible truth is that
$29.7 \%$ of school has no playground. $13.5 \%$ of school have a mediocre sized playground and $18.9 \%$ school consists of very small playground. These small playgrounds are not adequate for students. They can't play all kinds of games in these playgrounds.

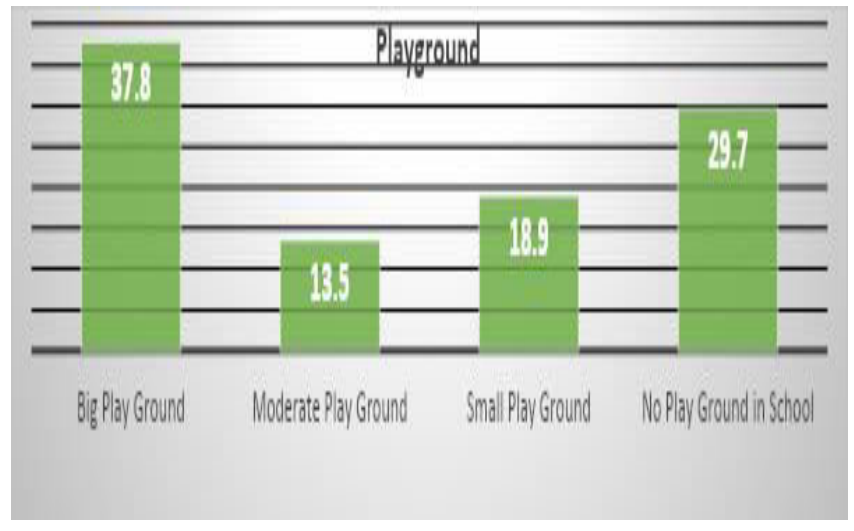

Fig 4: Playground facilities.

Qualitative investigation (FGD) findings: Almost all government primary school has big playgrounds and a little have moderate playgrounds. But maximum all non-government primary school have no play grounds. Diver's number of schools has very small playgrounds. Some teachers said to us that private school owners hold very commercial thinking. They just want to make money so they want to establish buildings, not playgrounds. 


\section{B. Regression Analysis}

The second section highlights Regression Analysis. The (Table 2, 3, \& 4) provided an output of regression model, ANOVA and Coefficients. Third tableModel Summary, fourth table-ANOVA, and fifth table provided Coefficients. P- Values are interpreted about the significance level of 0.05 . The model summary Table presents correlation between dependent and independent variable.
Results, Table 2 above point outs that, the simple liner correlation (R Square) shows positive correlation between dependent (Apparent of buildings) and independent variables (Total number of class rooms, Apparent of doors-windows and roofs, Total number of toilets) on performance of dropout. The R Square (R2) shows that $31.60 \%$ of dropout by performance of total number of class rooms, Apparent of doorswindows and roofs, Total number of toilets.

Table 2: Model Summary

\begin{tabular}{|c|c|c|c|c|c|c|c|c|c|}
\hline \multirow[b]{2}{*}{ Model } & \multirow[b]{2}{*}{$\mathbf{R}$} & \multirow[b]{2}{*}{ R Square } & \multirow[b]{2}{*}{ Adjusted R Square } & \multirow[b]{2}{*}{$\begin{array}{l}\text { Std. Error of the } \\
\text { Estimate }\end{array}$} & \multicolumn{5}{|c|}{ Change Statistics } \\
\hline & & & & & $\begin{array}{c}\text { R Square } \\
\text { Change }\end{array}$ & F Change & df1 & df2 & $\begin{array}{c}\text { Sig. F } \\
\text { Change }\end{array}$ \\
\hline 1 & $.562^{\mathrm{a}}$ & .316 & .254 & .504 & .316 & 5.078 & 3 & 33 & .005 \\
\hline
\end{tabular}

Source: Field data 2020. Significant Level $=0.05$

Table 3: ANOVAa

\begin{tabular}{|c|c|c|c|c|c|c|}
\hline \multicolumn{2}{|c|}{ Model } & Sum of Squares & df & Mean Square & F & Sig. \\
\hline \multirow{2}{*}{1} & Regression & 3.875 & 3 & 1.292 & 5.078 & $.005 \mathrm{~b}$ \\
\cline { 2 - 7 } & Residual & 8.395 & 33 & .254 & & \\
\cline { 2 - 7 } & Total & 12.270 & 36 & & & \\
\hline \multicolumn{2}{|l}{ a. Dependent Variable: Apparent of buildings } \\
\multicolumn{2}{|l}{ b. Predictors: (Constant), Total number of class rooms, Apparent of doors-windows and Roofs, Total number of toilets. } \\
\hline
\end{tabular}

Source: Research Data, 2020. Significant Level $=0.05$

Table 4: Coefficients table

\begin{tabular}{|c|c|c|c|c|c|c|}
\hline \multicolumn{7}{|c|}{ Coefficients } \\
\hline & \multirow{2}{*}{ Model } & \multicolumn{2}{|c|}{ Unstandardized Coefficients } & \multirow{2}{*}{\begin{tabular}{|c|} 
Standardized Coefficients \\
Beta \\
\end{tabular}} & \multirow[t]{2}{*}{$\mathbf{T}$} & \multirow[t]{2}{*}{ Sig. } \\
\hline & & B & Std. Error & & & \\
\hline \multirow[t]{4}{*}{1} & (Constant) & 4.178 & .306 & & 13.636 & .000 \\
\hline & Total Number of Class Rooms & .015 & .057 & .043 & .259 & .797 \\
\hline & Apparent of Doors-Windows and Roofs & -.383 & .117 & -.478 & -3.268 & .003 \\
\hline & Total Numbers of Toilet & -.193 & .081 & -.394 & -2.390 & .023 \\
\hline
\end{tabular}

Source: Research Data, 2020. Significant Level= 0.05

We discuss the regression model at the point of the data analysis technique. According to the following regression model, here:

\section{$Y=4.178+0.015 X 1-0.383 X 2-0.193 X 3$}

Where; $\mathrm{Y}=$ Apparent of Building (Reason of Dropout), $\beta \mathrm{o}=$ Constant, B1-B3 = Beta coefficients, $\mathrm{X} 1=$ Total numbers of classroom, X2 = Apparent of doors, UniversePG I www.universepg.com windows and roofs, $\mathrm{X} 3=$ Total numbers of toilet, $\mathrm{e}=$ Error Term. The beta coefficients exhibit the performance attributed to an adjustment in the predictor variables entirely others reasons keep hold on constant. Table 4 indicated that a unit change in Total Number of Class Rooms causes a 0.015 in Student dropout if other factors kept constant. Another unit change in Apparent of Doors-Windows and roofs cau- 
ses a -0.383 change in Students Dropout, while other factors kept constant, and the last unit change in Total Numbers of Toilet causes a -0.193 change in Students Dropout, while other factors held constant. Hypotheses were verified at a significance level of 0.05 . According to finding results reveals that in the coefficients Table 4 above, 'Total Number of Class Rooms' was found to be insignificant in affecting performance since a $\mathrm{P}$ value of 0.797 means the variable does not have a significant effect on 'Students Dropout'. One the other hand, 'Apparent of Doors-Windows and Roofs' has a significant effect on Stu-dent dropout because P-value is 0.003 . Besides, P-value of 0.023, Total Numbers of Toilet has a significant effect on Students Dropout. This model also used Braimah \& Oduro-Ofori, (2005). Their study on The Wise Man Builds His House upon the Rock the Effects of Inadequate School Building Infrastructure on Student Attendance (Branham, 2004). So, it wills great extent, if the education ministry has consented of Primary School's Infrastructure (Apparent of Doors-Windows, and Toilets) of Bangladesh.

\section{DISCUSSION:}

This study results found through using mixed method approaches which examined the student dropout by reasons of the output of Infrastructural facilities in the Bangladesh perspective. Around, several constraint and encounters for conducting this research. The data of this study were collected from four different districts in Bangladesh, but the process of data collection was not easy. They doubted surveyors for providing actual data. So, it was a little limitation for conducting actual scenario regarding student's dropout from the Primary education level. Besides this, we have been oppressed by the lack of books and journal's articles related to the infrastructure of primary schools. Even with these limitations, the study found a clear picture of the student Dropout from primary education level. It is especially true for the dependent and independent variables in this analysis that good portion of infrastructure quality on Student dropout (Branham, 2004). Finding information and data has been induced in both descriptive and statistical analysis by followed the SPSS program. This study reveals that the total student's dropout aver-age is $6.68 \%$, originated from $14 \%$ of school's Doors, Windows and Roofs that has been broken. Another reason for dropout is $62.2 \%$ of schools have no separate urinal system, $8.1 \%$ of Schools are traditional construction. That is why the measures of student dropout by using predicted dependent variables of 'Building Construction' and independent variables of 'Apparent of Doors-Windows and Roofs, \& Total Numbers of Toilets are positively correlated to reduce or control the student dropout rate. Research from Manhattan, New Your City identified that the School Building condition and dropout are positively correlated (Durán-Narucki, 2008).

The entire size of the student number of the study area was 10,779 . Among them, 145 students were dropout for infrastructural problems and the percentage is 6.68 . On the other hand, $27 \%$ of schools have 5 classrooms; maximum student dropout from class three and the percentage was $1.65 \% ; 30 \%$ Headmaster's office room was in moderated condition \& $5 \%$ in very bad condition; $32 \%$ general teacher's office room was in bad condition. $2.7 \%$ of schools have one office room for whole general teachers. On this issue, another research found that, if the school has infrastructure problems, then the dropout rate increases (Branham, 2004). 1,000 students can expect 10-13 more dropouts a year if the school has structural problems. By linking school survey data with data on student dropout in the study area, the authors developed a model of student's dropout that sequentially measures the effect on the probability of dropout during the schooling time. As also expected, family factor, age, parent's education, religions, marital status are also statistical factors affecting the possibility of dropout (Lloyd et al., 2000). But this study only used Infrastructural variables to see the dropout rate in a primary school in Bangladesh. Furthermore, the study results suggest that the entire number of classrooms, apparent of doors-windows and roofs and the entire number of toilets those requires more attention to reduce the rate of student dropout from the primary schools of Bangladesh. Further study might address the generalization of the infrastructure dropout consequence and why this is perfected in the primary schools of Bangladesh.

\section{CONCLUSION AND RECOMMENDATION:}

Every year some student drops out from the primary schools. But, through this study, we revealed that the infrastructural condition and the resources that school 
provides become insufficient for students, resulting in plenty of student's dropout. Students are not happy with the facilities they get from school and also from the teachers. Sometimes they have other reasons to left school and sometimes they have combined causes. The infrastructural crisis is the major cause amongst them. Many schools have very small areas, small playgrounds, dirty toilets and broken classrooms. Student's be-come discouraged and refuges to attend school. Here this study concludes, independent variables were found good measures of the specific dependent variable. This analytical section has many options to criticize with the contract of other studies in the proportion level. Moreover, this study also might remain an offering to the further policy building of the 'Ministry of Primary and Mass Education in Bangladesh'.

- The government of Bangladesh should keep an eye on the infrastructural facilities of primary schools. Sometimes the first impression is the best. So, when children find the infrastructural condition is not very good, they lose interest. For that reason, the government needs to take more initiatives on it.

- Water supply and sanitation system need to improve. The importance of using a toilet should explain to the students.

- We found plenty of school doesn't provide soap in toilets and the condition of the toilet is not so good. The school management committee should oversee it.

- In the rainy season, some school's roofs can't protect the students from the rainwater. These schools should repair the roof before the rainy season starts.

- The maximum number of schools doesn't have a separate urinal system and the school should provide it.

- The school doesn't conduct any survey among the students about the problems they go through. So, the school should conduct this kind of survey every year. Through this, they will identify the real problems.

- Several schools have no playgrounds and some has very small. That is a big problem for children to express their extra-curricular abilities. The school should provide a big playground.

- Enough number of classrooms should be provided.

UniversePG I www.universepg.com
- The furniture of the classroom should be beautiful and clean.

- The school needs to provide separate rooms or enough private circumstance for the teachers.

- All the primary schools should be made of bricks especially the schools situated in flood-affected areas. In the situation of over rainfall or flood, the vulnerable people of the locality could get shelter in the school building and plenty of lives could be saved.

\section{ACKNOWLEDGEMENT:}

We applied to the Gono Bishwabidyalay (University) administration for permission to lead this study. The administration grants the application. We are obliged to the teachers and some students of different schools who provided information for this study. That's why we acknowledge the cooperation of students and teacher. The study has no exact grant from any funding organization, agency and public and private institutions or profit and non-profit sectors. This work has been executed by the authors own funding capabilities.

\section{CONFLICTS OF INTEREST:}

There are no potential conflicts of interest among the authors of this article. In this study, Mahmudul Hasan and Md. Mokter Ali1 have equally contributed to the article as they are principal authors and Mst. Tahmina Sultana and Rehena Parvin contributed significantly to the paper as they are co-authors.

\section{REFERENCES:}

1) Alca'zar, L. \& Rogers, F. H. (2006). Why are teachers absent? Probing service delivery in Peruvian primary schools. Intern. J. of Edu. Res., 45, 117-136. https://doi.org/10.1016/j.ijer.2006.11.007

2) Annual Report, (2017-18). Ministry of Primary and Mass Education, Bangladesh.

3) Annual Primary School Census, (2018). Ministry of Primary and Mass Education \& Directorate of Primary Education, Bangladesh.

4) Benavot, A \& Gad, L. (2004). Actual instructional time in African primary schools: factors that reduce school quality in developing countries, $\mathbf{3}$, September 2004.

5) Bhunia, G. S., Shit P. K. \& Duary S. (2012). Assessment of School Infrastructure at Primary 
and Upper Primary Level: A Geospatial Analysis. J. of Geographic Information System, 4, 412-424. https://doi.org/10.4236/JGIS.2012.45047

6) Braimah I. \& Oduro-Ofori E. (2005). Basic school dropout in Ghana: A case study of the Amansie West district. $J$. of sci. and tech., 25(1), 67-76.

7) Branham, D. (2004). The Wise Man Builds His House Upon the Rock: The Effects of Inadequate School Building Infrastructure on Student Attendance, Soc. Science Quarterly, 85(5). 1112-1128.

8) Cairns, R. B., Cairns, B. D. and Neckerman, H. J. (1989). Early School Dropout: Configurations and Determinants, Child Develop., 60(6), 1437-1452.

9) Dhaka Tribune, (2017), School enrollment high but dropouts even higher, September 082017.

10) Durán-Narucki, Valkiria, (2008). "School Building Condition, School Attendance, and Academic Achievement in New York City Public Schools: A Mediation Model. " J. of Envir. Psych. 28(3): 278286. https://doi.org/10.1016/j.jenvp.2008.02.008

11) Farooq M. S. (2013). An inclusive Schooling Model for the Prevention of Dropout in Primary Schools in Pakistan. Bulletin of Education and Research, 35(1), 47-74.

12) Hanushek, E. A., Lavy, V. \& Hitomi, K. (2006). Do students care about school quality? Determinants of dropout behavior in developing countries. National bureau of economic research.

13) Houssemand, C. \& Meyers, R. (2013). The Role of Parenting in Dropping out of School: Contributions and Limits of Qualitative Research Methods. Elsevier Ltd., 523-528. https://doi.org/10.1016/j.sbspro.2013.08.887

14) Islam MJ. (2020). Factors influencing family size: a critical study on Khulna district of Bangladesh, Br. J. Arts Humanit., 2(4), 73-81. https://doi.org/10.34104/bjah.020073081

15) Janosz, M. \& Archambault, I. (2008). School Engagement Trajectories and Their Differential Pre- dictive Relations to Dropout. J. of Social Issues, 64(1), 21-40.

16) Lizettee, B. (2000). Background and rationale for school sanitation and hygiene education. UNICEF, New York, USA.

www.ircwash.org/.../background-and-rationale-schoo l-sanitation-and-hy

17) Lloyd C. B., Mensch B. S. \& Clarck W. H. (2000). The Effects of Primary School Quality on School Dropout among Kenyan Girls and Boys. Comparative Education Review, 44 (2), 113-147.

18) McCaslin M. \& Good T. L. (1992). The Misalliance of Management and Instructional Goals in Current School Reform. Edu.Resear., 21(3). 4-17.

19) Meremikwu, A. \& Enukoha, O. (2011) Instructional aids, school variables and pupils' mathematics achievement in primary schools in Cross River State, Nigeria. Res. in Mathe. Edu. 13(1), 87- 88. https://doi.org/10.1080/14794802.2011.550743

20) Murillo, F. J. \& Roma, M. (2011). School infrastructure and resources do matter: analysis of the incidence of school resources on the performance of Latin American students. School Effectiveness and School Improvement, 22(1), 29-50.

21) Petrosino, A. \& Morgan, C. (2012). Interventions in developing nations for improving primary and secondary school enrollment of children: A systematic review. Campbell Systematic Reviews, 19(1). https://doi.org/10.4073/csr.2012.19

22) The Independent, Editorial, (2016). Reasons behind primary school dropout in Bangladesh, 15 December 2016.

23) Zaman, M. M. (2014). Dropout at Primary and Secondary Level: A Challenge to Ensure Rights to Education for the Government of Bangladesh. Institute of Governance Studies (IGS), BRAC University, Pp 9-10. https://core.ac.uk/download/pdf/61807281.pdf

Citation: Hasan M, Ali MM, Sultana MT, and Parvin R. (2021). Impact of primary schools infrastructure on the dropout rate: a situational analysis on the context of Bangladesh, Br. J. Arts Humanit., 3(3), 64-73. https://doi.org/10.34104/bjah.021064073 () 